JURNAL KACAPURI

JURNAL KEILMUAN TEKNIK SIPIL

Volume 3 Nomor 2 Edisi Desember 2020

\title{
TINJAUAN KEKAKUAN STRUKTUR MENARA BANGUNAN MESJID AKIBAT POSISI PENEMPATAN STRUKTUR MENARA
}

\author{
Aminullah \\ Dosen Program Studi Teknik Sipil, Universitas Nahdlatul Ulama Banjarmasin \\ E-mail : aminullah.ak@gmail.com/HP. +62 813-5196-0007
}

\begin{abstract}
ABSTRAK
Struktur menara beton bertulang banyak dijumpai pada struktur bangunan masjid. Penempatan struktur menara seringkali tidak sesuai dengan desain awal. Penelitian ini membandingkan kekakuan dan stabilitas struktur menara masjid berdasarkan lokasi penempatan. Penempatan struktur menara di salah satu luasan bangunan masjid ditentukan sebagai model 1. Pemodelan struktur menara yang diletakkan di atas pelat atap (dak) ditentukan sebagai model 2. Studi kasus penelitian ini adalah struktur menara beton bertulang masjid Pusaka As-Su'ada, Hulu Sungai Utara, Banjarmasin. Struktur menara beton bertulang dimodelkan dengan menggunakan kombinasi idealisasi elemen cangkang 3D dan elemen 3D frame. Topi kerucut beton diberi beban terpusat dari berat sendiri mustaka. Analisis statik ekivalen telah dilakukan untuk meninjau stabilitas struktur menara. Hasil penelitian menunjukkan bahwa model 1 lebih stabil daripada model 2. Displasemen yang terjadi pada model 1 lebih rendah daripada model 2. Frekuensi alami yang terjadi berdasarkan hasil analisis modal menunjukkan tingkat kekakuan model 1 relatif lebih tinggi dari model 2 (35\%).
\end{abstract}

Kata Kunci : Mesjid, Menara, Stabilitas, Struktur, Modal

\begin{abstract}
The Reinforced concrete tower structures had been found easily in the mosque building structures. The placement of tower structures was not in accordance with the early design. This study compared the stiffness and stability of the mosque tower structure based on their placement. The placement of the tower structure where located in one area of the mosque had been determined as a model 1. The tower structure that where located on the roof plate was determined as a model 2. The case study of this research was the the reinforced concrete tower structure of the Pusaka As-Su'ada mosque, Hulu Sungai Utara, Banjarmasin. The reinforced concrete tower structure was modeled used an idealized combination of $3 D$ shell and $3 D$ frame elements. The concrete cone cap was given concentrated load as self weight of the mustaka. Equivalent static analysis has been performed to evaluate the stability of the tower structure. The results showed that model 1 was more stable than model 2. The displacement of model more llower than model 2. The natural frequency had been recorded in modal analysis showed that the stiffness level of model 1 is relatively higher than that of model 2 (35\%).
\end{abstract}

Keywords: Mosque, Tower, Stability, Structure. Modal 
JURNAL KACAPURI

JURNAL KEILMUAN TEKNIK SIPIL

Volume 3 Nomor 2 Edisi Desember 2020

\section{PENDAHULUAN}

Struktur menara beton bertulang banyak dijumpai pada struktur bangunan masjid. Penempatan struktur menara seringkali tidak sesuai dengan desain awal. Penelitian ini membandingkan kekakuan dan stabilitas struktur menara masjid berdasarkan lokasi penempatan. Penempatan struktur menara di salah satu luasan bangunan masjid ditentukan sebagai model 1. Pemodelan struktur menara yang diletakkan di atas pelat atap (dak) ditentukan sebagai model 2. Studi kasus penelitian ini adalah struktur menara beton bertulang masjid Pusaka As-Su'ada, Hulu Sungai Utara, Banjarmasin. Struktur menara beton bertulang dimodelkan dengan menggunakan kombinasi idealisasi elemen cangkang 3D dan elemen frame 3D. Topi kerucut beton diberi beban terpusat dari berat sendiri mustaka. Analisis statik ekivalen telah dilakukan untuk meninjau stabilitas struktur menara.

\section{TINJAUAN PUSTAKA}

\section{Struktur Mesjid}

Mohamad Kusyanto dkk. (2018) telah melakukan penelitian tentang pembangunan masjidmasjid. Model pembangunan berbasis partisipasi masyarakat berkembang pada pembangunan masjid secara meluas di berbagai daerah di Indonesia. Di dalam model pembangunan ini kemampuan ekonomi dan tenaga serta pengetahuan membangun yang dimiliki masyarakat umumnya terbatas, sehingga membutuhkan strategi pembangunan masjid yang tepat. Berdasarkan hasil kajian proses pembangunan sejumlah masjid berkubah yang dibangun dengan partisipasi masyarakat pada umumnya dilaksanakan secara bertahap sehingga diduga berpengaruh pada kualitas bangunan terutama pada pemenuhan kaidah-kaidah strukturnya. Penelitian ini menggunakan metode kuantitatif pada sejumlah masjid berkubah yang memiliki struktur soko guru dan tidak sebagai penopang kubah beton. Analisis data dilakukan dengan menerangkan kaidah struktur melalui analisis perbandingan struktur pada kedua jenis struktur masjid dengan menggunakan 'rule of the thumb' dan software ETABS versi 9.6. Hasil penelitian menunjukkan bahwa pemenuhan kaidah struktur masjid berkubah dipengaruhi oleh dua faktor utama yaitu: 1) kemampuan ekonomi masyarakat dan 2) tingkat pengetahuannya. Selain itu sejumlah faktor lain yang turut mendukung strategi pembangunan masjid berkubah meliputi lama waktu membangun dan ketersediaan desain bangunan. Secara umum masjid berkubah memiliki struktur aman dan cukup wajar sehingga memunculkan beberapa alternatif struktur penopang kubah. Meskipun demikian masjid tanpa soko guru relatif kurang aman dibandingkan dengan masjid dengan soko guru dalam menahan beban arah ortogonal yang lebih besar seperti gempa.

Nangkula dan Mohamad (2010) telah melakukan penelitian tentang arsitektur Islam, khususnya arsitektur masjid modern di Malaysia, belum dilakukan secara intensif. Sebagian besar kajian dan dokumentasi yang dilakukan lebih terfokus pada kajian masjid-masjid tua yang dinilai lebih bernilai historis dengan arsitektur tradisional yang lebih unik. Tulisan ini akan mencoba mendeskripsikan tipologi bentuk dan gaya visual masjid (sebagai bangunan utama arsitektur Islam) yang berkembang di Malaysia, mulai dari masjid tradisional di kawasan pelosok desa hingga masjid di perkotaan. Kajian ini sangat penting dalam mengenali aspek morfologi, pengaruh, dan perkembangan desain masjid di Malaysia yang akan menjadi 
JURNAL KACAPURI

JURNAL KEILMUAN TEKNIK SIPIL

Volume 3 Nomor 2 Edisi Desember 2020

acuan dalam mendesain masjid, khususnya di negara ini di masa yang akan datang. Pembahasannya sendiri akan terdiri dari Arsitektur Masjid Tradisional Vernakular Malaysia, Masjid Eklektik Sino di Malaysia, Masjid Klasik Eropa di Malaysia, Masjid India Utara di Malaysia, Masjid Modern Vernakular Malaysia, Masjid Modern Ekspresionisme Revivalisme di Malaysia.

Endang (2016) Arsitektur Indonesia, telah melakukan penelitian tentang salah satu simbol peradaban Islam Masjig Agung Kraton Yogyakarta. Masjid Agung Kraton Yogyakarta merupakan salah satu ragam arsitektur islami Jawa. Spesifikasi masjid agung menjadi bagian penting dari keraton Yogyakarta. Itulah obyek penelitian yang menarik. Bangunan bangunan masjid tersebut mampu menopang hingga saat ini, dengan performanya yang indah dan sarat nilai seni. Strukturnya harus dirawat dan dirawat dengan baik. Penelitian ini bertujuan untuk mengeksplorasi struktur ragam masjid jawa islam. Metode penelitian yang berkualitas dengan pendekatan sejarah, budaya dan agama yang akan digunakan dalam penelitian ini. Analisa dengan argumentasi logis akan dilakukan. Hasil penelitian menunjukkan bahwa dalam enam pola struktur yang memiliki budaya sikritisme, yaitu Islam, Jawa, Budha Hindu, dan Kolonial, yang terlihat pada ragam hias struktur.

\section{Stabilitas}

Čaušević dan Rustempašić (2012) telah melakukan studi dari sebuah kegiatan proyek rehabilitasi Masjid Ferhad-Pasha. Tujuan dari proyek ini adalah untuk membangun sebuah bangunan asli dengan menggunakan bahan asli, dengan tetap menghormati prinsip estetika dan pendekatan para pembangun kuno. Bangunan tersebut akan direkonstruksi ke kondisi yang sama seperti sebelum dihancurkan dengan metode konstruksi yang serupa. Diperkirakan akan sulit untuk mematuhi prinsip ini, karena perkembangan arsitektur yang signifikan sejak awal konstruksi. Monumen adalah benda berharga yang harus dihormati, dan sesedikit mungkin diubah. Pengamatan ini dapat mengarah pada keputusan yang kontradiktif, terkadang menerima tingkat risiko yang lebih tinggi untuk menghindari atau membatasi perubahan pada konsep asli. Masjid Ferhad-Pasha adalah karya seorang mimar (pembangun) dan muhendis (insinyur) yang berkualifikasi tinggi, produk dari sekolah Sinan. Pada tanggal 7 Mei 1993, masjid itu dinamit dan diratakan dengan tanah, dan materialnya dipindahkan ke tempat pembuangan akhir kota di Ramiće.

Program komputer SAP 2000 digunakan untuk menganalisis menara dengan elemen cangkang. Dengan asumsi tidak ada tegangan, ditemukan bahwa tegangan melebihi tingkat yang lebih besar di bawah beban gempa. Deformasi yang disebabkan oleh gaya geser memiliki pengaruh yang tidak signifikan terhadap kekakuan struktur tinggi ramping, sehingga dapat diabaikan dalam perhitungan praktis. Untuk mengurangi tegangan tarik, yang muncul akibat gerakan seismik, kami merekomendasikan dua solusi.

Miftahul Iman (2011) telah melakukan penelitian tentang stabilitas dan tentang begitu banyak kegagalan struktur yang diakibatkan oleh persoalan stabilitas, terutama pada komponen struktur yang menerima beban aksial. Berdasarkan teori dan praktek, jenis tumpuan yang berbeda akan memberikan pola tekuk yang berbeda juga. Perbedaan ini akan berakibat kesalahan dalam analisa beban kritis yang dengan sendirinya menjadi tidak akurat lagi. Pertimbangan keakuratan dan ketepatan dalam prediksi beban kritis ini maka telah banyak 
JURNAL KACAPURI

perangkat lunak dari analisa struktur yang telah dikembangkan, khususnya analisa tekuk dan SAP2000 adalah salah satunya. Penelitian ini berfokus pada kajian numerik yang berdasarkan pada metode elemen hingga dari sebuah batang aksial tekan yang mempertimbangkan kelangsingan untuk mendeskripsikan kegagalan tekuk. Model pengujian diperoleh dari salah satu sampel penelitian oleh Miftah (2010) yang menggunakan galvanized pipe sebagai batang tekan yang dimodelkan sebagai circular hollow section, CHS. Selanjutnya dengan bantuan SAP2000 versi 11,00 akan dibuat pendekatan batang tersebut dengan model 3D frame dan model 3D shell dengan menambahkan spherical dome shell pada ujung-ujung model tersebut untuk kemudan dilakukan analisis dengan analisa statik untuk tekuk linier. Akhirnya kedua model tersebut dibandingkan dan kemudian dari keduanya akan dilakukan verifikasi terhadap nilai eksak (Euler analisis) dan hasil uji eksperimen. Hasil penelitian menunjukkan bahwa dengan melakukan penambahan spherical dome pada ujung-ujung cylindrical shell model akan membuat beban aksial terkosentrasi pada tumpuan dalam hal ini menggunakan tumpuan sederhana sehingga akan memberikan pola tekuk yang serupa dengan model Euler satu dimensi. SAP2000 versi 11 memberikan ketelitian yang sangat tinggi terhadap hasil analitik yaitu $0,028 \%$. Selain itu, dari kombinasi spherical dome-cylindrical shell pada SAP2000 versi 11,00 juga memberikan ketelitian yang cukup baik yaitu $-5,47 \%$ dan menunjukkan bahwa dengan model ini beban kritis yang dicapai jauh lebih konservatif dibandingkan dengan menggunakan model 3D frame.

Erdogan dkk. (2010) Menara Seljuk Anatolia menunjukkan karakteristik yang mirip dengan Menara Ottoman Klasik dan lebih ramping dan semua bagian dibangun secara keseluruhan dibandingkan dengan menara pada periode sebelum Anatolia. Elemen pijakan menara yang tidak terlihat di Menara Turki sebelum Anatolia pertama kali terlihat di menara Seljuk Anatolia. Elemen pondasi adalah bagian transisi yang menyediakan dan memperlunak transisi struktural antara tiang kubik yang lebih lebar dan badan poligon atau silinder yang lebih ramping, juga mengintegrasikan dua bagian struktural secara statis dan visual, dan sebagai tambahan membantu menara untuk tahan terhadap gempa. Semua bagian menara dicapai ke tingkat puncak pada Periode Ottoman. Dalam studi ini, penampilan seismik dari dua menara (Menara Masjid Selimiye di Edirne milik Periode Ottoman dengan Menara Masjid Madrasah Menara Ince di Konya milik periode Anatolia Seljuk) akan dibandingkan. Penampilan seismik dari menara-menara ini pertama kali dimodelkan dalam tiga dimensi dengan menggunakan program komputer SAP2000 dan kemudian diselidiki dengan Analisis Pushover sesuai dengan TEC-2007 (Kode Gempa Turki, 2007). Perkembangan masonry minaret custom telah dibahas dengan temuan yang didapat. Selain itu, temuan ini akan dijadikan data untuk restorasi menara batu.

\section{METODOLOGI PENELITIAN}

Penempatan struktur menara di salah satu luasan bangunan masjid ditentukan sebagai model 1. Pemodelan struktur menara yang diletakkan di atas pelat atap (dak) ditentukan sebagai model 2. Studi kasus penelitian ini adalah struktur menara beton bertulang masjid Pusaka AsSu'ada, Hulu Sungai Utara, Banjarmasin. Struktur menara beton bertulang dimodelkan dengan menggunakan kombinasi idealisasi elemen cangkang 3D dan elemen frame 3D. Topi kerucut beton diberi beban terpusat dari berat sendiri mustaka. Analisis statik ekivalen telah dilakukan untuk meninjau stabilitas struktur menara. 


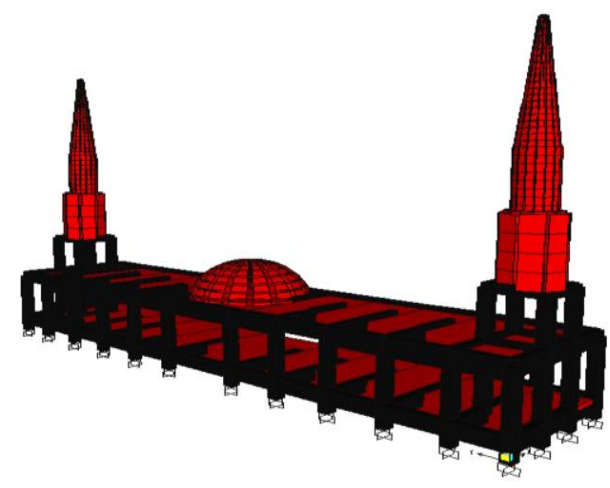

(i)

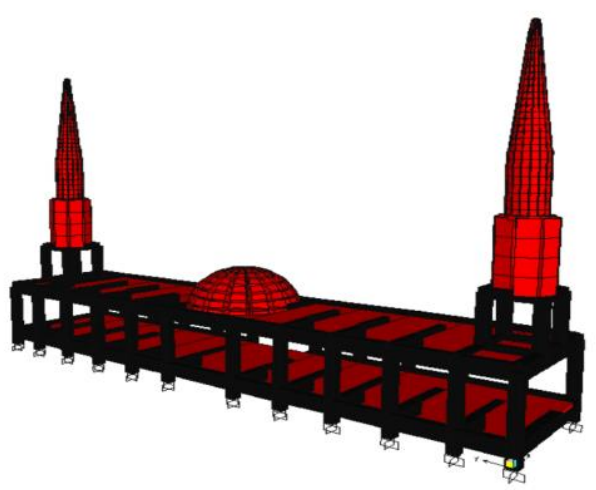

(ii)

Gambar 1 Pemodelan numerik masjid As-Su'ada

Gambar 1 menunjukkan pemodelan numerik struktur menara masjid As-Su'ada, Hulu Sungai Utara Banjarmasin. Model 1 (Gambar 1(i)) menunjukkan struktur menara yang ditumpu dengan empat kolom yang terhubung dengan pelat fondasi beton bertulang. Gambar 1(ii) adalah model 2 dengan struktur menara yang hanya diletakkan diatas struktur pelat atap beton bertulang (dak). Kedua model memiliki diskretisasi elemen cangkang sama.

Kombinasi pembebanan yang diberikan berturut-turt adalah kombinasi beban gravitasi $(1,2 D$ $+1,6 L)$ dan kombinasi beban lateral gempa $(1,2 D+1,0 L+1,0 E)$ dengan $D$ adalah beban mati, $L$ adalah beban hidup, dan $E$ adalah beban gempa. Kombinasi beban gempa diberikan dalam 2 arah dengan asumsi kedua arah memilik potensi seismik (beban gempa) yang sangat besar. Data tanah diasumsikan sebagai tanah lunak (tipe E).
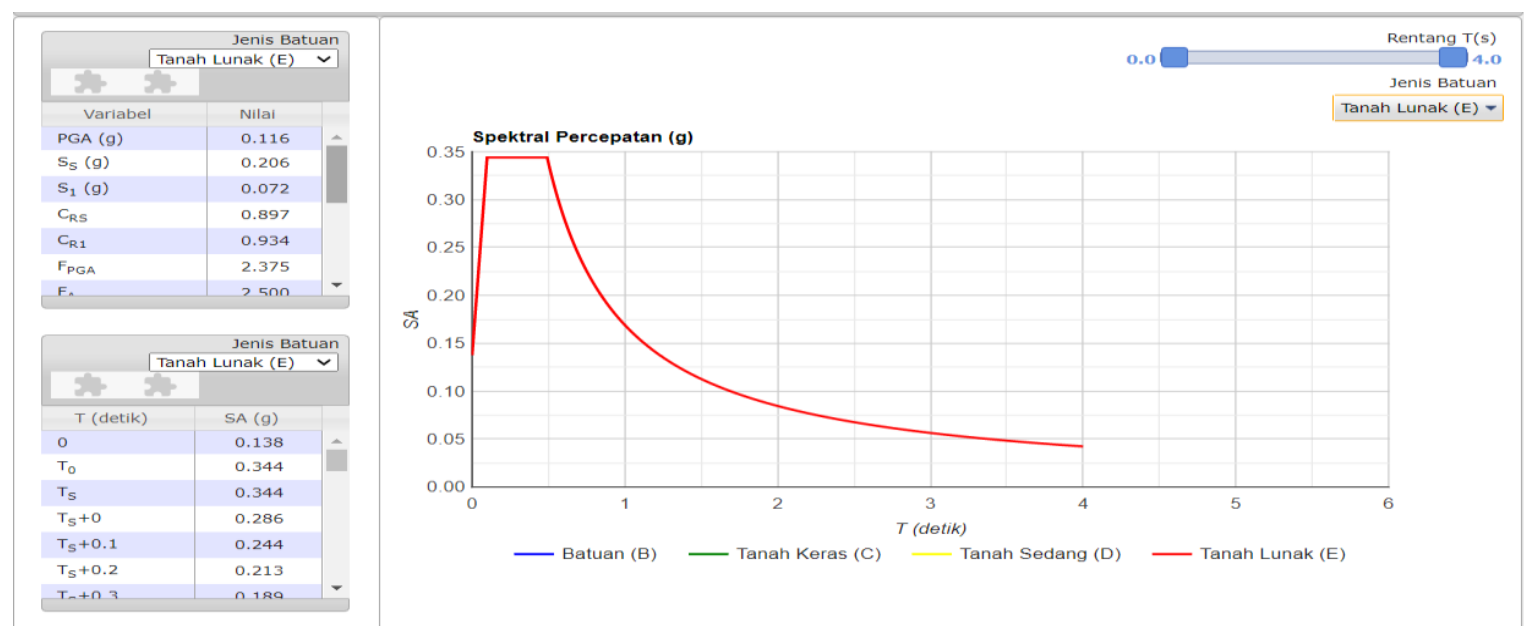

Gambar 2. Parameter gempa yang digunakan

Secara umum tahapan penelitian diawali dengan penilaian kinerja struktur menara bangunan masjid (building assessment) yang meliputi pemeriksaan mutu bahan dan desain awal struktur. 
Tahapan kedua adalah pemodelan numerik dengan melibatkan parameter-parameter yang dievaluasi dan kombinasi pembebanan yang digunakan. Hasil penelitian disajikan dalam bentuk komparasi hasil analisis strutur kedua model dengan beberapa kombinasi pembebanan yang diberikan. Tahapan penelitian dapat dilihat pada bagan alir (Gambar 3).

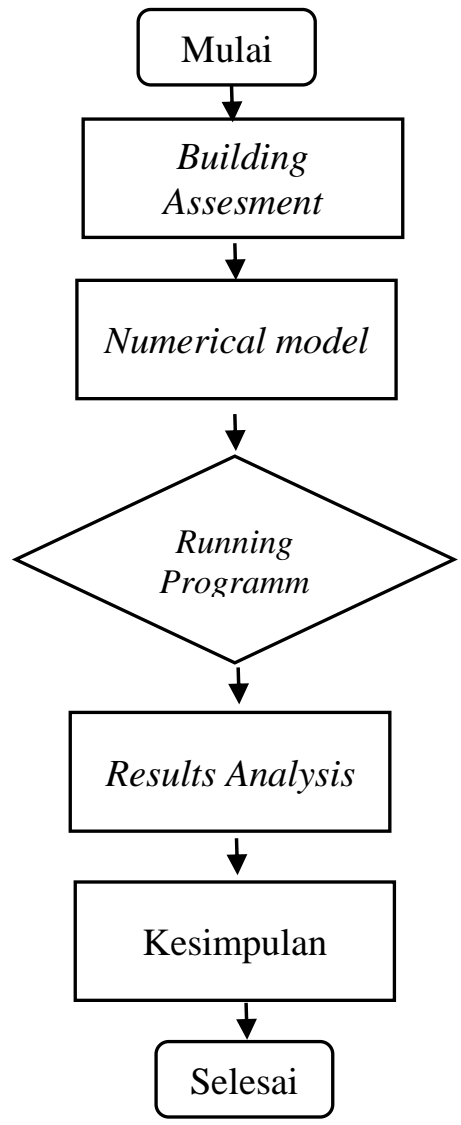

Gambar 3. Bagan alir penelitian 


\section{HASIL DAN PEMBAHASAN}

Hasil riset ini dibagi menjadi dua kelompok besar, berturut-turut yaitu tinjauan stabilitas dan kontrol tegangan. Tinjauan stabilitas meliputi analisis modal dan kontrol displasemen akibat kombinasi pembebanan. Kontrol tegangan dilakukan untuk mengevaluasi kemungkinan retak yang terjadi pada struktur menara masjid.

\section{Tinjauan Stabilitas}

\section{Analisis modal}

Hasil tinjauan analisis modal dari kedua model penempatan struktur menara dapat dilihat pada Tabel 1.

Tabel 1. Frekuensi analisis modal

\begin{tabular}{lcccccc}
\hline Model & \multicolumn{7}{c}{ Mode } \\
\hline & $\mathbf{1}$ & $\mathbf{2}$ & $\mathbf{2}$ & $\mathbf{4}$ & $\mathbf{5}$ & $\mathbf{6}$ \\
\hline Model 1 & 3,5873 & 3,7264 & 3,7456 & 3,7692 & 7,6713 & 7,7928 \\
Model 2 & 2,3262 & 2,3696 & 3,3804 & 3,4147 & 6,6733 & 7,2119 \\
\hline
\end{tabular}

Tabel 1 menunjukkan bahwa struktur menara dengan kolom menerus sampai dengan fondasi (model 1) memiliki frekuensi lebih tinggi dari struktur menara dengan kolom yang hanya ditumpu oleh pelat atap (model 2). Hal tersebut menunjukkan bahwa Model 1 memiliki kekakuan yang relatif lebih tinggi daripada model 2. Tabel 1 juga menunjukkan perubahan frekuensi pada Model 1dan Model 2 lebih besar dari mode 4 ke mode 5 (3,7692 - 7,6713 dan $3,4147-6,673)$.

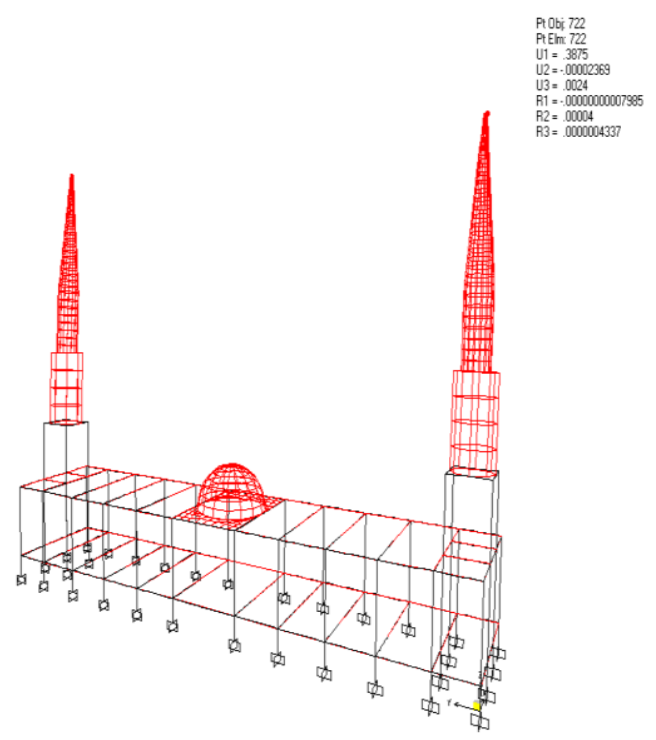

Modal 4

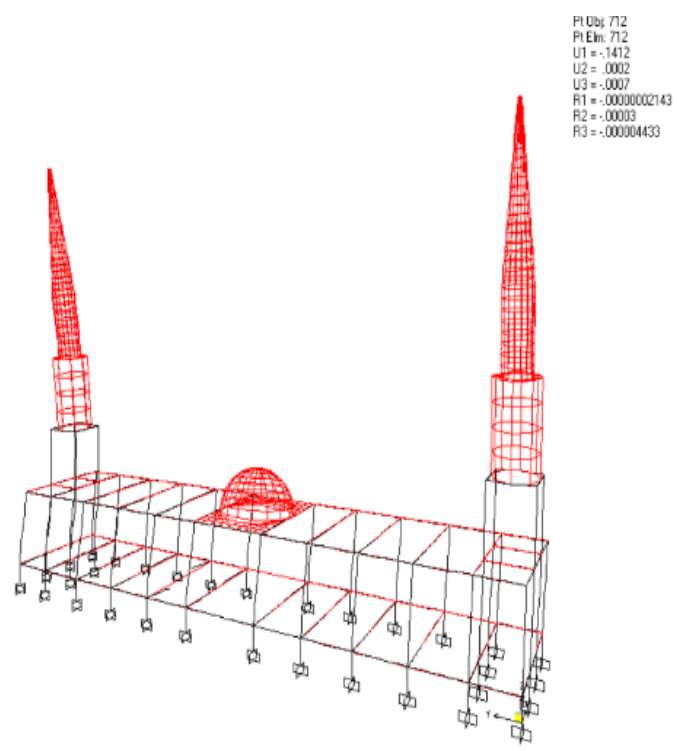

Modal 5

Gambar 4 Deformasi struktur model 1 analisis modal 
Gambar 4 menunjukkan bahwa terjadi perubahan bentuk struktur yang cukup signifikan dari mode 4 menuju mode 5 . Kedua menara bergerak berturut-turut mode 4 dan mode 5 pada arah berlawanan $(\operatorname{arah}-x)$. Penelitian ini juga telah mengevaluasi displasemen yang terjadi pada salah satu nodal di puncak menara (Tabel 2).

Tabel 2. Displasemen nodal 744 mode 1 analisis modal

Model Displasemen, mm

\begin{tabular}{lcccccc}
\hline & $\mathbf{U}_{\mathbf{7 4 4}}$ & $\mathbf{V}_{\mathbf{7 4 4}}$ & $\mathbf{W}_{\mathbf{7 4 4}}$ & $\boldsymbol{\theta x 1}$ & $\boldsymbol{\theta x 2}$ & $\boldsymbol{\theta x 3}$ \\
\hline Model 1 & $-3,0 \mathrm{E}-4$ & $-3,7 \mathrm{E}-1$ & $-3,47 \mathrm{E}-5$ & $-4,0 \mathrm{E}-5$ & 0 & 0 \\
Model 2 & $1,98 \mathrm{E}-5$ & $3,5 \mathrm{E}-1$ & $1,0 \mathrm{E}-3$ & $-4,0 \mathrm{E}-5$ & 0 & 0 \\
\hline
\end{tabular}

Tabel 2 juga menunjukkan bahwa pada nodal 744 (puncak menara) cenderung tidak terjadi rotasi untuk kedua model tersebut. Posisi penempatan kolom menara pada konstruksi masjid sangat menentuan kekakuan. Penempatan kolom menara pada pelat atap cenderung lebih stabil daripada penempatan kolom menara pada pelat lantai. Hal tersebut ditunjukkan oleh displasemen yang terjadi pada nodal 744 model 1 relatif lebih besar $(3,0 \mathrm{E}-4 \mathrm{~mm})$ daripada displasemen yang terjadi pada nodal yang sama dari model 2 (1,98E-5 mm). Arah displasemen yang ditinjau dalam model ini adalah arah-x (U).

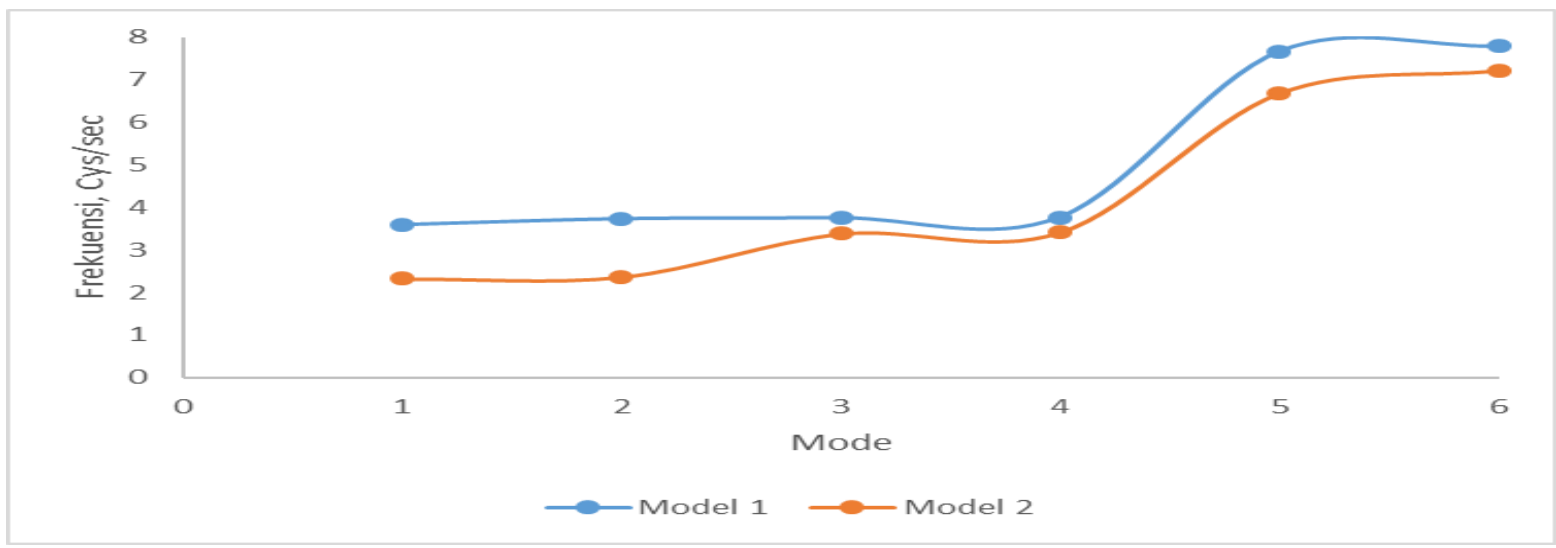

Gambar 5. Kurva perbandingan frekuensi

Gambar 5 menunjukkan kurva perbandingan frekuensi antara Model 1 dan Model 2 berdasarkan pengamatan 6 modal. Perbedaan frekuensi yang sangat signifikan terlihat pada mode 1 dan mode 2, berturut-turut 35,15\% dan 36,14\%. Gambar 5 juga menunjukkan tren kenaikan frekuensi struktur menara seiring dengan bertambahnya kenaikan jumlah mode. Lonjakan frekuensi struktur menara masjid dari mode 4 ke mode 5 berkisar 50,87\% (Model 1) dan 48,83\% (Model 2). 
JURNAL KACAPURI

JURNAL KEILMUAN TEKNIK SIPIL

Volume 3 Nomor 2 Edisi Desember 2020

\section{Analisis struktur statik ekivalen (kombinasi beban gempa)}

Hasil tinjauan displasemen analisis struktur statik ekivalen dari kedua model penempatan struktur menara dapat dilihat pada Tabel 3 dan Tabel 4 dengan kombinasi beban 1,2D+L+E.

Tabel 3. Displasemen nodal Model $1(1,2 D+1,0 L+1,0 E)$

\begin{tabular}{lcccccc}
\hline Model 1 & \multicolumn{7}{c}{ Mode } \\
\hline Kombinasi beban & $\mathbf{U}_{744}$ & $\mathbf{V}_{\mathbf{7 4 4}}$ & $\mathbf{W}_{744}$ & $\boldsymbol{\theta} \mathbf{x}_{\mathbf{1}}$ & $\boldsymbol{\theta} \mathbf{x}_{\mathbf{2}}$ & $\boldsymbol{\theta} \mathbf{x}_{\mathbf{3}}$ \\
\hline $1,2 \mathrm{D}+1,0 \mathrm{~L}+1,0 \mathrm{Ex}$ & 5,4382 & 0,01 & 0,3654 & 0 & 0,00057 & 0 \\
$1,2 \mathrm{D}+1,0 \mathrm{~L}+1,0 \mathrm{Ey}$ & 0,0002 & 5,9947 & $-0,3647$ & $-0,0006$ & 0 & 0 \\
\hline
\end{tabular}

Tabel 3 menunjukkan bahwa perpindahan (displacement) pada nodal 744 (puncak menara akibat kombinasi beban gempa arah y $(1,2 \mathrm{D}+1,0 \mathrm{~L}+1,0 \mathrm{Ey})$ relatif lebih besar dari kombinasi beban gempa arah $x(1,2 D+1,0 L+1,0 E x)$ yaitu $9,28 \%$. Hal ini disebabkan oleh geometrik denah masjid yang lebih memanjang ke arah sumbu $y$.

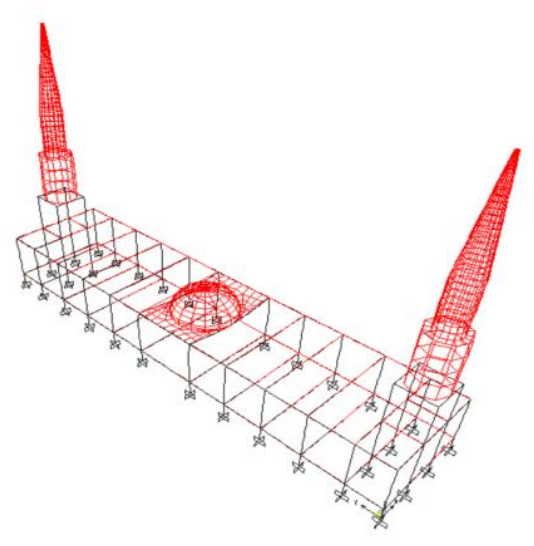

$\operatorname{Arah} x$

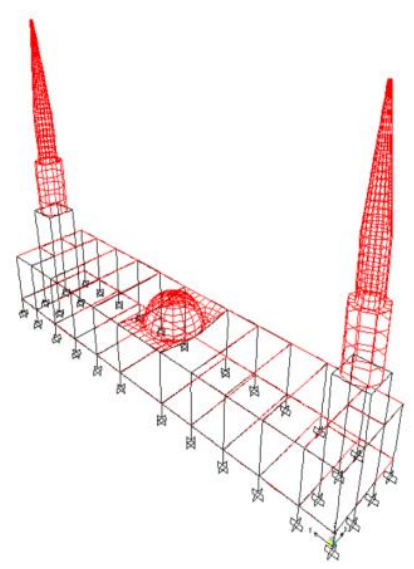

Arah $y$

Gambar 6. Deformasi struktur model 1 analisis statik ekivalen

Gambar 6 menunjukkan bahwa deformasi struktur menara pada kombinasi beban gempa arah$y$ cukup signifikan dari deformasi akibat kombinasi beban gempa arah $x$. Gambar 6 juga menunjukkan bahwa struktur menara yang terletak di sisi kanan struktur bangunan masjid relatif lebih memiliki simpangan yang cukup besar ketika gempa arah $-x$ bekerja. Sebaliknya, struktur menara yang terletak pada sisi kanan bangunan masjid relatif tidak berubah ketika kombinasi beban gempa arah-y bekerja pada model 1 . 


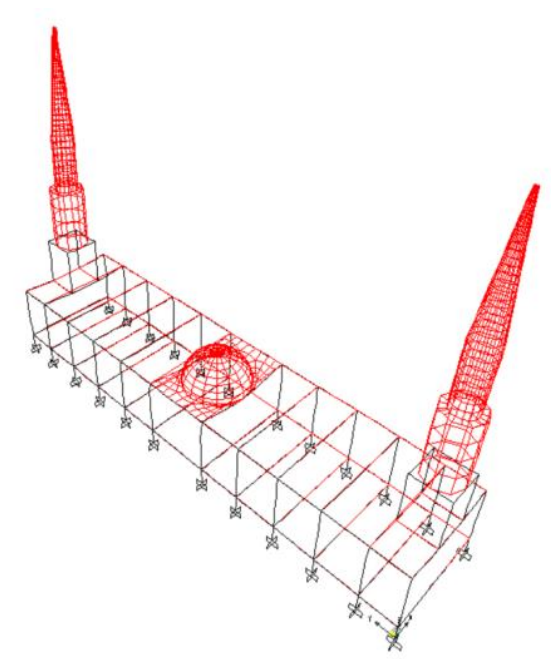

$\operatorname{Arah} x$

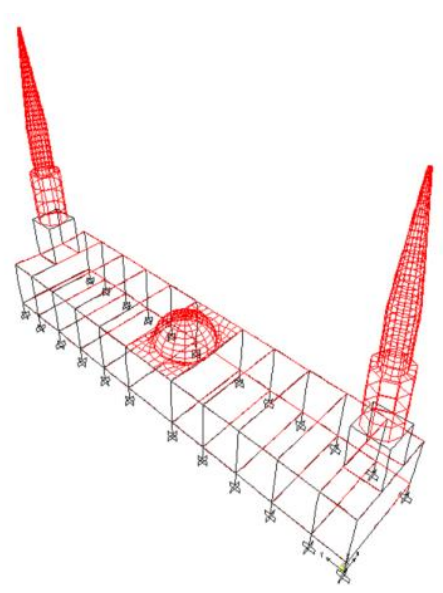

Arah $y$

Gambar 7. Deformasi struktur model 2 analisis statik ekivalen

Gambar 7 menunjukkan bahwa deformasi struktur menara pada model 2 akibat bekerjanya kombinasi beban gempa arah-y tidak terlalu signifikan dari deformasi akibat bekerjanya kombinasi beban gempa arah $x$. Gambar 7 juga menunjukkan bahwa struktur menara yang terletak di sisi kanan struktur bangunan masjid relatif memiliki smpangan yang relatif kecil (dibandingkan dengan model 1) ketika gempa arah $-x$ bekerja. Sebaliknya, struktur menara yang terletak pada sisi kiri bangunan masjid relatif memiliki simpangan yang cukup besar pada arah-y bekerja pada model 2.

Tabel 4. Displasemen nodal Model $2(1,2 D+1,0 L+1,0 E)$

\begin{tabular}{lcccccc}
\hline Model 2 & \multicolumn{7}{c}{ Mode } \\
\hline Kombinasi beban & $\mathbf{U}_{744}$ & $\mathbf{V}_{744}$ & $\mathbf{W}_{744}$ & $\boldsymbol{\theta} \mathbf{x}_{\mathbf{1}}$ & $\boldsymbol{\theta} \mathbf{x}_{\mathbf{2}}$ & $\boldsymbol{\theta} \mathbf{x}_{\mathbf{3}}$ \\
\hline $1,2 \mathrm{D}+1,0 \mathrm{~L}+1,0 \mathrm{Ex}$ & 6,42 & $-0,514$ & 1,614 & $5 \mathrm{E}-5$ & $6,6 \mathrm{E}-4$ & 0 \\
$1,2 \mathrm{D}+1,0 \mathrm{~L}+1,0 \mathrm{Ey}$ & $3,0 \mathrm{E} 4$ & 12,877 & $-1,57$ & $-1,25 \mathrm{E}-3$ & 0 & 0 \\
\hline
\end{tabular}

Tabel 4 menunjukkan bahwa perpindahan (displacement) pada nodal 744 (puncak menara akibat kombinasi beban gempa arah y $(1,2 \mathrm{D}+1,0 \mathrm{~L}+1,0 \mathrm{Ey})$ relatif lebih besar dari kombinasi beban gempa arah $x(1,2 D+1,0 L+1,0 E x)$ yaitu 50,14\%. Hal ini disebabkan oleh geometrik denah masjid model 2 yang lebih memanjang ke arah sumbu $y$.

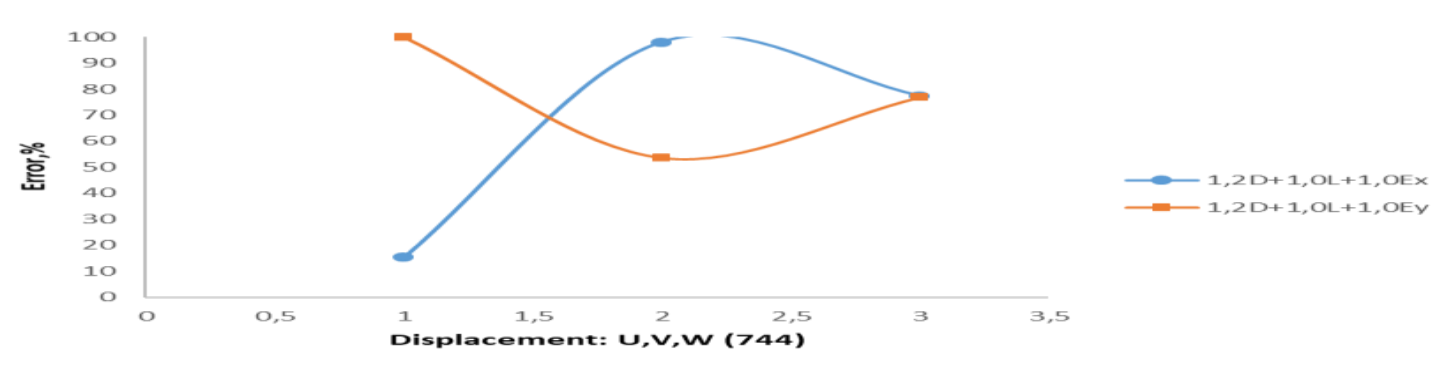

Gambar 8. Kurva perbandingan displasemen nodal 744 akibat kombinasi beban gempa 
Gambar 8 menunjukkan perbandingan kurva displasemen pada nodal 744 (ujung menara) sebelah kanan masjid akibat kombinasi beban gempa. Displasemen yang ditinjau berturut-turut adalah displasemen translasi $U$ (arah- $x), V(\operatorname{arah}-y)$ dan $W(\operatorname{arah}-z)$. Rotasi yang terjadi pada nodal 744 relatif kecil (mendekati nol). Gambar 8 juga menunjukan bahwa nodal 744 akan berpindah maksimum ketika kombinasi beban gempa arah- $x$ bekerja dan minimum pada nodal yang sama ketika kombinasi beban gempa arah-y bekerja pada kedua model. Displasemen arah- $y(W)$ pada nodal 744 ketika tidak terdapat perbedaan pada kedua model dan pada kedua kondisi pembebanan. Hal tersebut juga menunjukan bahwa hampir tidak terdapat perbedaan displasemen signifikan yang disebabkan oleh beban gravitasi $(D)$ untuk kedua model tersebut.

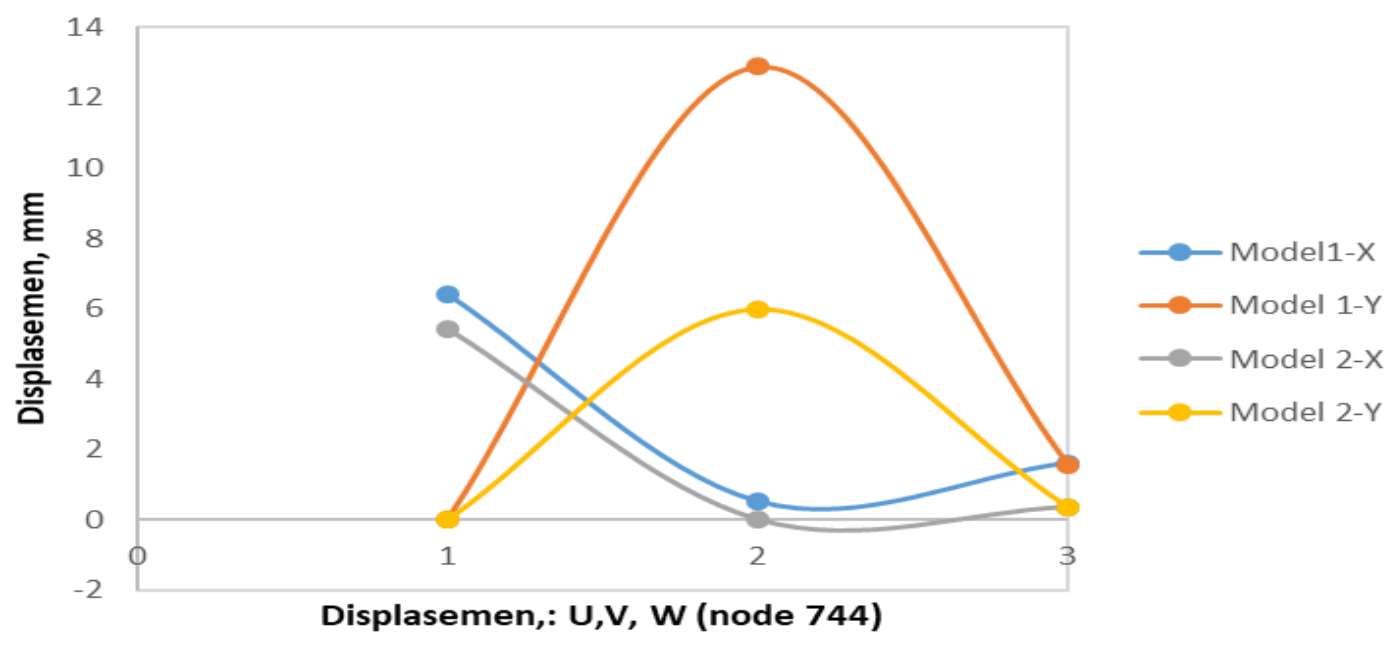

Gambar 9. Kurva perbandingan displasemen akibat kombinasi beban gempa

ambar 9 menunjukkan kurva perbandingan displasemen dari kedua model struktur menara dan 2 arah kombinasi pembebanan $(x$ dan $y$ ). Displasemen yang ditinjau hanya pada displasemen translasi saja $(U, V$, dan $W)$. Gambar 9 juga menunjukkan bahwa displasemen terbesar terjadi pada model 2 (menara diletakkan di atas pelat atap) dalam arah- $y$. Hal ini menunjukkan bahwa Model 2 lebih tidak stabil daripada Model 1 terutama akibat kombinasi beban gempa yang bekerja pada arah-y atau searah dengan sumbu memanjang bangunan masjid.

Persentase perbedaan antara Model 1 dan Model 2 berturut-turut adalah 15,29\%; 98,05\%; dan 77,36\% untuk arah $-\mathrm{x}$ sedangkan untuk arah $-\mathrm{y}$ berturut-turut adalah 33,33\%, 53,46\% dan $76,77 \%$. Persentase perbedaan terbesar ditunjukkan displasemen translasi $V$ (arah-y) Model 1 $(98,05 \%)$. Hal tesebut menunjukkan bahwa simpangan terbesar menara pada nodal yang dimonitor (nodal 744) terjadi simpangan yang lebih besar ketika struktur menara berdeformasi searah sumbu memanjang (arah y) akibat kombinasi beban gempa $1,2 D+1,0 L$ dan $1,0 E_{y}$.

Penelitian ini juga telah mengevaluasi tegangan yang terjadi, berturut-turut akibat kombinasi beban $1,2 D+1,5 L ; 1,2 D+1,0 L+1,0 E_{x}$ dan $1,2 D+1,0 L+1,0 E_{y}$ dengan $D$ adalah beban mati, $L$ adalah beban hidup, $E_{x}$ adalah beban gempa arah- $x$ dan $E_{y}$ adalah beban gempa arah $y$. Tegangan yang dievaluasi adalah tegangan maksimum yang bekerja pada permukaan struktur menara yang terletak pada sisi kanan bangunan masjid As-Suada. 


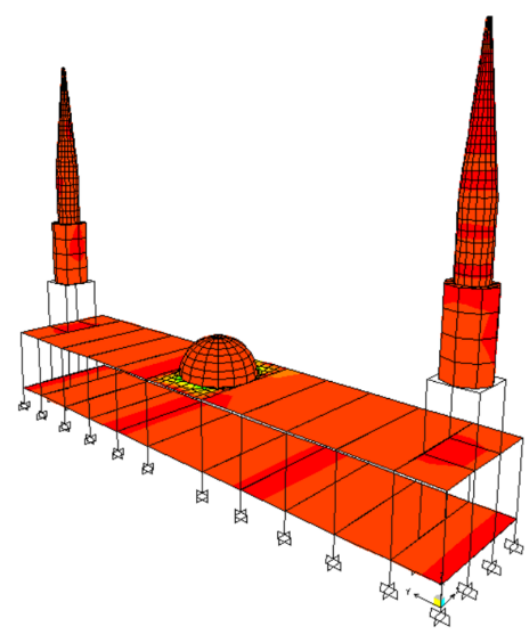

(i)

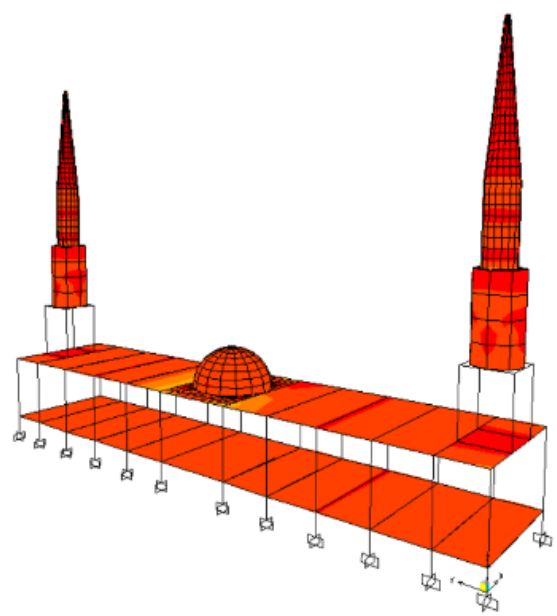

(ii)

Gambar 10. Kontur tegangan kombinasi beban 1,2D + 1,6L

Gambar 10 menunjukkan kontur tegangan maksimum (Smax) yang terjadi pada permukaan menara untuk kedua model perletakan menara akibat kombinasi beban gravitasi $(1,2 D+1,6 L)$. Kisaran tegangan maksimum (Smax) yang terjadi pada Model 1 (Gambar 8(i)) adalah -0,017 MPa sampai dengan $+0,017$ Mpa. Gambar 8(ii) menunjukan bahwa kisaran tegangan maksimum (Smax) pada Model 2 adalah -0,40 MPa sampai dengan +0,40 MPa. Hal tersebut menunjukkan bahwa tegangan yang terjadi pada kedua model struktur menara tersebut lebih kecil dari mutu beton rencana (K175) atau dengan kata lain kedua model struktur menara tersebut masih aman akibat kombinasi beban gravitasi.

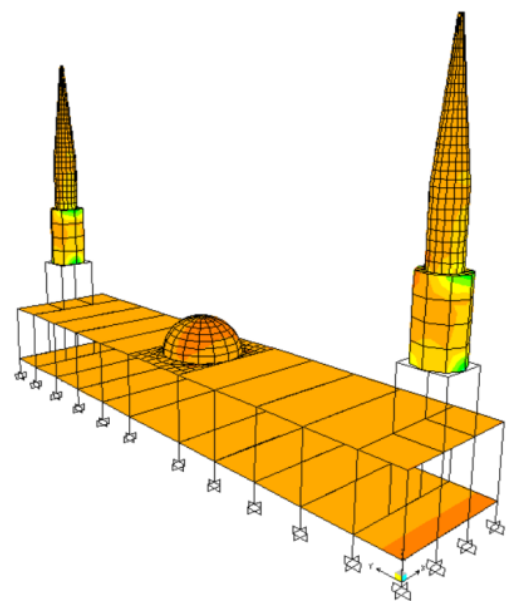

(i)

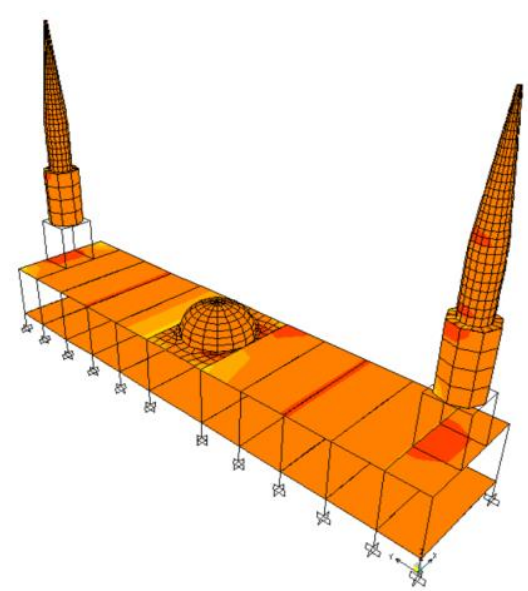

(ii)

Gambar 11. Kontur tegangan kombinasi beban gempa $\left(1,2 D+1,0 L+1,0 E_{y}\right)$

Gambar 11 menunjukkan kontur tegangan maksimum (Smax) yang terjadi pada permukaan menara untuk kedua model perletakan menara akibat kombinasi beban gempa (seismic; $1,2 D$ $\left.+1,0 L+1,0 E_{y}\right)$. Kombinasi beban gempa arah y dipilih karena memiliki displasemen yang 
relative lebih besar daripada kombinasi beban gempa arah-x. Kisaran tegangan maksimum (Smax) yang terjadi pada Model 1 (Gambar 11(i)) adalah -0,26 MPa sampai dengan +1,56 MPa. Gambar 9(ii) menunjukan bahwa kisaran tegangan maksimum (Smax) pada Model 2 adalah -0,45 MPa sampai dengan +1,80 MPa. Hal tersebut menunjukkan bahwa tegangan tekan yang terjadi pada kedua model struktur menara tersebut lebih kecil dari mutu beton rencana (K175). Nilai tegangan maksimum positif (tarik) lebih besar dari mutu beton rencana (K-175). Hal ini sangat berbahaya bagi kondisi struktur menara khususnya dan struktur bangunan masjid pada umumnya. Struktur menara akan mengalami kegagalan akibat beban lateral gempa (seismic) di sisi tari struktur menara pada arah-y untuk kedua model tersebut.

\section{Kesimpulan}

\section{PENUTUP}

Berdasarkan hasil penelitian dapat disimpulkan sebagai berikut:

1. Model 1 memiliki kekakuan yang relatife lebih tinggi daripada Model 2 berdasarkan waktu getar alami yang dimiliki masing-masing model $(T)$.

2. Displasemen Model 1 terukur pada ujung atas menara (nodal 744) yang terletak di sisi kanan bangunan mesjid terjadi lebih rendah daripada Model 2.

3. Frekuensi alami yang terjadi berdasarkan hasil analisis modal menunjukkan tingkat kekakuan model 1 relatif lebih tinggi dari model 2 (35\%).

4. Pengaruh kombinasi beban lateral gempa arah-y lebih dominan terhadap kedua model terutama Model 2.

5. Secara umum struktur menara untuk kedua model masih dapat dikatakan aman berdasarkan nilai tegangan kombinasi beban gravitasi tetapi, sangat penting untuk diperhatikan bahwa struktur menara memiliki resiko yang tinggi mengalami kegagalan struktur pada sisi tarik akibat kombinsai beban lateral seismic arah- $y$.

\section{Ucapan Terimakasih}

Penulis mengucapkan terimakasih kepada rekan-rekan Dosen di lingkungan Program Studi Teknik Sipil, Fakultas Teknik, Universitas Nahdlatul Ulama Banjarmasin serta semua pihak yang telah banyak membantu kelancaran dan selesainya penelitian ini.

\section{DAFTAR PUSTAKA}

1. Čaušević A., Rustempašić N., 2012. Evaluation of stability of masonry minaret in high seismicity region-the case of the Ferhad-Pasha's Mosque Minaret. https://www.researchgate.net/publication/259642051_Evaluation_of_stability_of_mason ry_minaret_in_high_seismicity_region_-_the_case_of_the_Ferhad-

_Pasha's_Mosque_Minaret.

2. Endang S., 2016. Keragaman Struktur Bangunan Masjid Islam Jawa (Studi kasus : Bangunan Masjid Gedhe Keraton Yogyakarta). Prosiding Seminar Nasional Sustainable Architecture and Urbanism 2016 Universitas Diponegoro.

3. Erdogan H.A., Basar M.E., Sezer R., Kara N., 2010. Structural Analysis Comparing The Minarets of The Selimiye Mosque with Ince Minaret Madrasa. Proceedings of the 8 th ICCAE-8 Conference, 25-27 May, 2010.

4. Mohamad K., Sugeng T., Surjamanto W., Mohammsd D. R., 2018, Pemenuhan Kaidahkaidah Struktur pada Masjid Berkubah yang Dibangun Berbasis Partisipasi Masyarakat. Temu Ilmiah Ikatan Peneliti Lingkungan Binaan Indonesia (IPLBI) 7, G 075-083 https://doi.org/10.32315/ti.7.g075.

5. Nangkula U., Mohamad T.M.R., 2010. Deskripsi Tipologi, Klasifikasi dan Analisis Perancangan Masjid di Malaysia, el-Harakah. Vol.12 No.3. Malaysia. 